\title{
Solar Energy in Oman: Performance and Efficiency
}

\author{
Asmaa Khalfan Saif Al-Falahi
}

Solar energy is power uses in various techniques to concentrate the energy of the sun and converted into electricity and then supplies it for thousands of people. Furthermore, solar energy efficiency and performance still law it around 15\% $-21.5 \%$ ranging for solar crystalline silicon. Besides that, Oman has a good graphical location for applied solar energy technologies and an increase in efficiency and performance of using solar energy technologies can make economic future development which can help to reduce the dependence on fossil fuels and create a sustainable environment that can make a change in Omani economic diversification. Acutely, the main objective of this research is to study the performance of solar energy in building and enhance solar energy efficiently in Oman. The research methods that used are qualitative and quantitative which are questionnaire and interview that analyzed by using SPSS program and narrative analysis. Moreover, the result analysis of this research display that the performance of solar energy can be improving by Make solar technology clean, install solar energy technology correctly, Provide solar concentrator and avoid the shaded area. Additionally, the efficiency of solar energy can be increased by using many technologies as solar cell glazing, cooling technique Concentrators, and Solar tracking.

\section{Introduction}

Solar energy is the energy technology used to harness the energy of the sun and make it possible to use. Normally, this energy can be made by using semiconductor cells material. The sun's energy hits the semiconductor cells and the electrons moveable from their particles. Then, the electricity will be generated by the electron flow through semiconductor cells. The solar energy power uses in various techniques to concentrate the energy of the sun and converted into electricity and then supply it for thousands of people (Solar Energy, 2018).

Solar energy technology is a popular choice for a lot of owners, businesses and organizations who are searching for generating greener energy and save their energy bills. Therefore, there are different types of solar energy technologies that have been applied in the building in different countries as Photovoltaic Solar Technology, Concentrating Solar Energy, Passive Solar Energy and Active solar energy (Massey, 2019).

The efficiency of solar energy and performance can be defined as the ability of sunlight energy to convert it into electrical energy. Moreover, it used to measure the ability of Solar panel to convert the sunlight energy into electrical energy with the same duration and the same amount of sunlight at low cost and high supply rate (Aggarwal, 2019)

Solar energy efficiency and performance is one significant topic that becomes overstep in technology for now and the future as well. The efficiency of solar energy depends on three factors which are solar radiation intensity, the quality of solar energy technology and operating temperature of materials as semiconductor cells. There are many researchers and developers being improved and researched. Naturally, solar energy efficiency and performance still law it around $15 \%-21.5 \%$ ranging for solar crystalline silicon but still researcher being carried out in order to improve solar energy efficiency technology, for example, A solar cell glazing, Solar tracking, Cooling technique and Concentrators (John, 2019) 


\section{Journal of Student Research}

Fourth Middle East College Student Research Conference, Muscat, Sultanate of Oman

There are different types of solar energy that can be applied in the building and used as solar panels, Concentrating Solar Energy, passive solar system and active solar system. Each of these solar types has different performance in the building which is available in the market. Monocrystalline solar panels have more performance and efficiency than polycrystalline and thin-film but it is more expensive and the heaviest ones to install on the roof of the building. However, the polycrystalline panel is middle in both cost and performance. Moreover, it is lighter than monocrystalline. Thin-film solar is less performance as well as cheaper than other types but, it is flexible and the lightest one. Therefore, there is a different performance of solar energy technology types as per the product quality and company brand as well as their performance. Furthermore, selection suitable type of solar energy in the building with high performance can produce good performance for the building with a long lifetime (John, 2019)

Shade can affect the performance of solar energy technology by shading the sun's energy and a ray of solar energy technology which can waste the performance and efficiency of solar energy technology. Avoid the shade as branches, chimneys, or other between the peak hours of 9 am to 3 pm can a chive good performance as well as high efficiency of solar energy technology. Moreover, keep solar technology cleans can increase performance because dirt has bad effect on the performance of solar technology. Furthermore, dust accumulates on the solar energy equipment as glass surface of solar panel which reduces performance due to disposal to receive sunlight on the solar panel (Bullis, 2019).

A rugged robot is the last modifying of report cleaning by the researcher which is used for clean dust in the desert area because the desert is very dusty which can affect the performance of solar energy panels. It can lose about $0.4-0.8 \%$ efficiency per day. The rugged robot is mounted on tracks along rows of solar panel and it works one time per day. It passes over the panels and cleans them with a brush design without required of water (Eclache, 2016)

\section{Efficiency and performance of solar energy}

One important way to increase solar energy efficiency and performance of the solar panels technologies is making an informed decision while purchasing solar energy technology and deciding to use solar technology in the building. This way can find the best offers for saving money and get good performance for selected solar energy technology type for the building. Moreover, decide to install solar energy in the building required to be aware of a number of the solar panels that required installing in the building and the daily electricity target that need as well.

Furthermore, be awareness of newer technology of solar energy that is using in the building and check out the solar technology type which has more efficiency can improve the performance of solar in the building (Morgan, 2019)

Site selection for solar energy technology and placement in the building is one criterion that can help to increase efficiency and performance of solar energy technology. The location of the building in the solar map radiation and awareness of amount of sun ray in-country can increase efficiency of solar energy technology because of the amount of the sunray is from 4.2 and above in the solar map mean that place has more sun radiation which can increase efficiency of solar energy and work better than another country that has low sun radiation. Moreover, solar energy panels need to orient in the right direction and angle to receive as much sun" radiation as possible in a day. This step is required experienced and qualified installers who ha ability to orient amount arrays optimally in the building (Massey, 2019).

The quality of solar energy technology can affect the efficiency and performance of output power. There are many companies that produce solar energy technology in different quality as per the production of solar energy equipment. For example, the solar photovoltaic cell is comprised of silicon which is important to determine affecting output. If purity of silicon cell is made by good quality the efficiency of output power will increase (Author, 2019). 


\section{Journal of Student Research}

Fourth Middle East College Student Research Conference, Muscat, Sultanate of Oman

There are a number of experiments that have done to increase solar energy technology efficiency and output by providing utilities to solar energy technology. Solar energy panel has many researched in experimental technologies and highest efficiencies as Multi-cell gallium arsenide that has the highest efficiency which is $44 \%$ and Single-cell gallium arsenide has $29 \%$ efficiency. The Crystalline silicon has 25\% efficiency and thin-film copper-indium -gallium selenide has $20 \%$ efficiency. The Emerging PV technology has the lowest efficiency which is 11\% (Eclache, 2016).

A solar cell glazing is used for producing solar cells from elements rain, snow; bird dropping, etc. it has high optical transmissivity $90 \%$ which can use surface coating treatment to reduce reflections for higher transmissivity. Moreover, solar tracking is one of important utilities that use for increasing the efficiency of output for solar energy technology. It used for solar energy panels to rotate the array of penal to directly face the sun all day. It has driven by a clock motor which uses for following the sun. It can increase solar energy efficiency by up to $70 \%$ but, it increases the cost of solar energy panels. Furthermore, Concentrators is one way that uses to focus the sunlight by using mirrors in order to increase the efficiency of solar energy panels. The mirror should be larger than solar panels to collect the sunlight from large space to small space for solar panels. This way can increase solar energy efficiency by $50 \%$. (Eclache, 2016).

The cooling technique is used to reduce high temperature for solar energy panels because overheating reduce the efficiency of solar energy panels. The hybrid photovoltaic solar system is one of popular technique that used for cooling the solar energy panels. It contains solar energy photovoltaic combined with the cooling system. Water is used for cooling the solar cell by circulating around the solar energy panel and warm water is leaving the panel pump and back to water tank. Warm water and cool water are mixed together in water tanks (Nazar, 2016)

\section{Oman Solar Energy}

Solar energy is a strategic solution to provide electricity in the sultanate of Oman due to the availability of solar energy resource and large lands are unused. It has the opportunity to development and deployment of solar energy which can make good economic benefits and environmental as well. Solar energy can provide energy for present demand and future generation which can create a cleaner and sustainable environment. Oman's location has the opportunity to receive a tremendous amount of solar radiation and the annual sun average is between 6 to 6.5 daily sun radiations that are the highest in the world. Furthermore, Oman has 25 locations that the average daily sunshine duration and solar radiation are high which Marmul has the highest solar radiation followed by Fahud, Sohar and Qairoon Haiti. Moreover, the desert area has the highest insolation of solar energy that other coastal area (Kaleem, 2017)

One of the largest solar energy projects that have a plant capacity of 200MW which development in Dakhiliya rejoins that uses a grouping of focused solar power and photovoltaic technology as showing in figure 1: Miraah solar project. Miraah Solar Project is one of the biggest projects in Oman that commence of plant construction was in October 2015 and the first stem was produced in November 2017. It was contracted to construct by Petroleum Development Oman (PDO). A joint venture between Oman government, Shall, Total and Partex. It successes to exist 7MW pilot plant in February 2013 and the plant was officially installed in February 2018. It uses harness of the sun „energy to produce steam that used in Oil production (Observer, 2019) 


\section{Journal of Student Research}

Fourth Middle East College Student Research Conference, Muscat, Sultanate of Oman

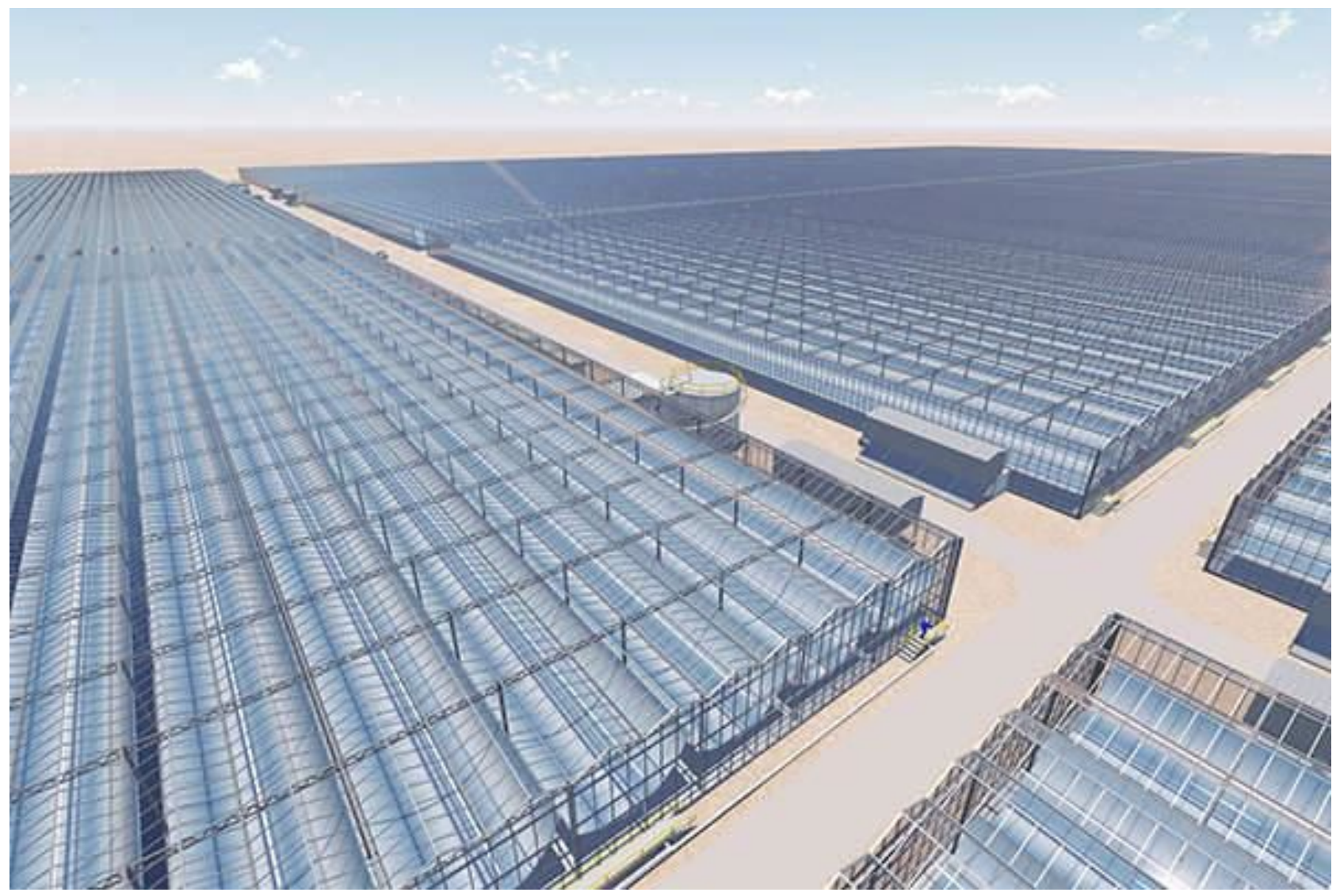

Figure 1. Miraah solar project

Solar into a school named of international oil companies (Shall) project that shall carry out the solar installation in school in a different location in Oman in 2017 that helps to contribute energy of Oman transition by reducing demand of grid-supplied electricity by at least $150 \mathrm{MW}$ per year of each school as showing in figure 2: Solar into school (Investment, 2019) 


\section{Journal of Student Research}

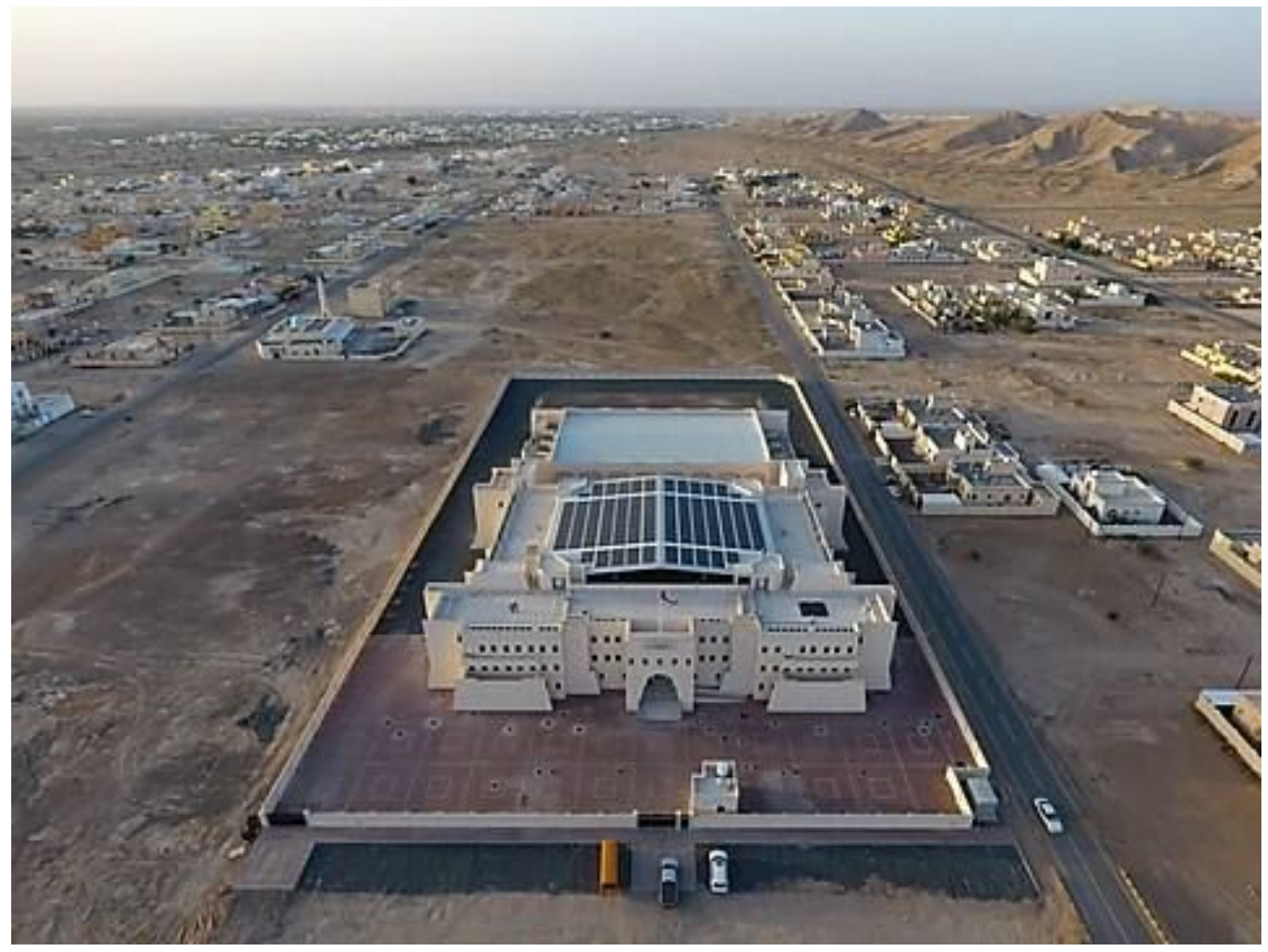

Figure 2. Solar into school

\section{Research methodology}

The data collection methods that apply in this project are qualitative and quantitative which are questionnaires and interviews. The questionnaire was made with clear questions and reliable ways to be able to manage and collect data that commensurate with the objective and question of the research project. Moreover, the interview was used to support questionnaire results to achieve the objective. Normally, it is face to face discussion with humans which required using notes or tape to record the answer of the interview. The interview question can be either closed or open and it is not required a short answer.

The secondary data that has used in this research are books, internet web-site and the same journal papers. It used to collect data from another research study that done in other place and different period. The benefit of using this data is to increase knowledge that commensurate with the objective and question of research. Moreover, it used to assist the result that has been collected from questionnaires and interviews. The primary data that are used in this research are questionnaires and interviews. The questionnaires and interviews have inducted in different organizations private and government as well. The private company as Construction Company who has been involved in construction solar energy technology project as a contractor and Majan electrical company, Knowledge Oasis Muscat (KOM) and Sultan Qaboos University. Moreover, the oil company which is starting to make a new investment by using solar energy technology and government ministry of environment as Authority for electricity regulation Oman and public Authority for water (Diam).

The method used to analyze the questionnaire is Computer software which is SPSS short of statistical package for the social sciences that many researchers used for analyzing complex statistical data. The result can be analysis by using SPSS which can identify the mean, standard deviation for questions and also measure the coefficient of question and test of the hypothesis. Moreover, Narrative analysis is the analysis method used to analyze interviews. It becomes popular increasing in social sciences. It aims to make sense of stories. 


\section{Result analysis}

The result question „Please rate the different methods of increase performance of solar energy in building which are Avoid shaded area, Install solar energy technology correctly, Provide solar concentrator to solar energy technology and make solar technology clean by using Self-cleaning technology" the responses have answered as following as per percentage of strongly agree and the mean and standard deviation as showing in figure3: methods of increase performance of solar energy in building:

- Make solar technology clean by using Self-cleaning technology has the highest response of strongly agree as $38.89 \%$ and the mean is 3.89 and standard deviation is 1.213

- Install solar energy technology correctly has $35.95 \%$ of response and the mean is 3.83 and the standard deviation is 1.208

- Provide solar concentrator to solar energy technology has $30.00 \%$ and the mean is 3.74 and the standard deviation is 1.195

- Avoid shaded area has $27.78 \%$ and the mean is 3.76 and the standard deviation is 1.154

Figure 3. Methods of increase performance of solar energy in building

The result analysis of question „Could you please estimate the percentage of increasing efficiency of using Solar tracking, Cooling technique, solar cell glazing and Concentrators in the solar energy panels in Oman" has the following estimating of response as per more than $50 \%$ and mean and standard deviation as showing in figure 4: estimate the percentage of increasing efficiency :

- solar cell glazing has $57.78 \%$ and the mean is 3.64 and standard deviation is 1.266

- The Cooling technique has $49.44 \%$ and the mean is 3.72 and the standard deviation is 1.323

- Concentrators has $40 \%$ and the mean is 3.78 and the standard deviation is 1.331

- Solar tracking $40 \%$ and the mean is 3.4 and the standard deviation is 1.475

Figure 4. Estimate the percentage of increasing efficiency

The result analysis of question „Enhance performance of solar energy panels and increase its efficiency can save money for long time used and make solar panels service long" has $42.22 \&$ of response as agree and $27.78 \%$ of response as strongly agree while it has $6.67 \%$ of response as strongly disagree and $8.89 \%$ of response as disagreeing and the mean is 3.74 and standard deviation is 1.154 which is normal curve as showing in below figure 5: Enhance performance of solar energy panels and increase its efficiency.

Figure 5. Enhance performance of solar energy panels and increase its efficiency

\section{Result discussion}

The data collection from questionnaire data and interviewer and has agreed from previous 
literature as follows:

\section{Methods of increase performance of solar energy in building}

- Install the solar energy technology correctly in the roof of the building and with right direction and angle

- Avoid any shaded area that covers the sunlight from solar panels

- Make solar technology clean by clearing it monthly or provide Self-cleaning technology.

- Provide solar energy technology by concentrator which used to focus sunlight into solar panels to improve the performance of solar energy panels

\section{Ways of enhancing the efficiency of solar energy technology in solar panels}

- Solar Tracking

- Cooling Technique

- Solar Cell Glazing

- Concentrators

\section{Factors affecting conversion efficiency in solar energy}

- Manufacturers

- Temperature

- Wavelength

- Reflection

\section{Conclusion}

To sum up, performance of solar energy can be used to measure the quality of the work achieve for solar technology output whither is good or bad while the efficiency of solar energy is measured the work done by using ratio which is mathematic calculation and different meaning between performance of solar energy and efficiency is good performance with poor efficiency will be accepted but nobody will accept bad efficiency without good performance. Furthermore, the performance of solar energy in the building can be improving by using many ways from the beginning of the construction of solar energy panels. Firstly, install solar energy technology correctly in the roof of the building and with the right direction and angle. Secondly, avoid any shaded area that covers the sunlight from solar panels and Make solar technology clean by clearing it monthly or provide Self-cleaning technology. Moreover, it provides solar energy technology by concentrator which used to focus sunlight into solar panels to improve the performance of solar energy panels. Moreover, the efficiency of solar energy depends on three factors which are solar radiation intensity, the quality of solar energy technology and the operating temperature of materials as semiconductor cells. The efficiency of solar energy can be increased by adding technology in solar panels as solar tracking, Cooling technique, solar cell glazing, and Concentrators. Moreover, there is the factor that effecting conversion efficiency in solar energy is 


\section{Journal of Student Research}

Fourth Middle East College Student Research Conference, Muscat, Sultanate of Oman

temperature and heat due to it has the ability to damage the materials in panels, therefore, law temperature and heat can make solar panels to work better and for a long time. Moreover, improving solar panels material by using a multi-junction layer in panels can improve efficiency and increase it. Furthermore, high quality of semiconductors it cans conversion good efficiency and minimizing the amount of sunlight that has reflected away from solar panels surface.

\section{Acknowledgements}

My thanks go to my family for continuous support me to make my dream become true.

Furthermore, I would thank some managers and employees in the different organizations as government sector as well as the private sector for their knowledge and support about solar energy efficiency and performance in Oman. Moreover, I would to thank the academic written unit and Student Success Center for help and support to achieve this project. Many thanks go to the Supervisors and Professors in the Civil Engineer department for their instructions and checking which assist me to achieve this research project.

\section{References}

Solar Energy. (2018, December 22). Retrieved April 2, 2019, from nationalgeographic: <https://www.nationalgeographic.com/environment/global-warming/solar-power/>

Aggarwal, v. (2019). Solar Panel Efficiency: What Panels Are Most Efficient? |. Retrieved March 19, 2019, from Energysage: <https://news.energysage.com/what-are-the-most-efficient-solar-panels-onthe-market/>

Author, M. (2019). An Idea To Increase The Efficiency Of Solar Panel And To Research On The Air Conditioning System From Same Solar Panel Itself. Retrieved June 10, 2019, from instructables: $<$ https://www.instructables.com/id/An-Idea-to-Increase-the-Efficiency-of-Solar-Panel-/>

Bullis, K. (2019). How To Double The Power Of Solar Panels. Retrieved June 15, 2019, from technology review: <https://www.technologyreview.com/s/429586/how-to-double-the-power-of-solarpanels/>

Eclache, p. (2016). Improvement Of Conversion Efficiency And Enhancement In Output Power Of Solar Panel. International Journal Of Science And Research, 56-59.

Investment, s. L. (2019). Solar Into Schools. Retrieved June 2019, 23, from Shell:

<https://www.shell.com.om/en_om/sustainability/social-investment/solar-into-schools.html>

John, S. (2019, June). How To Improve The Efficiency Of Solar Panels - The Renewable Energy Hub. Retrieved June 19, 2019, from renewable energy : < https://www.renewableenergyhub.co.uk/main/s olar-panels/how-to-improve-the-efficiency-of-solar-panels/>

Kaleem, A. (2017, january 26). solar energy in Oman. Retrieved April 26, 2019, from ecomena : http://www.ecomena.org.

Massey, D. (2019). 4 Tips To Increase Efficiency Of Roof-Mounted Solar Panels - Construction21. Retrieved June 19, 2019, from construction: <https://www.construction21.org/articles/h/4-tips-toincrease-efficiency-of-roof-mounted-solar-panels.html>

Morgan, k. (2019). The Advantages Of Radiant Floor Heating Systems. Retrieved June 15, 2019, from Doityourself: <https://www.doityourself.com/stry/radiantfloorheat>

Nazar, R. (2016). mprovement Of Conversion Efficiency And Enhancement In Output Power Of 
Solar Panel. International Journal Of Science And Research (IJSR) 5 (3), 56-59.

Observer, O. (2019). PDO, Glasspoint Inaugurate Miraah Solar Plant. Retrieved june 22, 2019, from Oman observer: <http://www.omanobserver.om/pdo-glasspoint-inaugurate-miraah-solar-plant/ 